\title{
Digitális egyenlőtlenségek és digitális tőkemegoszlás Romániában
}

A tanulmány a digitális egyenlőtlenségek és a digitális tőkemegoszlás romániai helyzetét vizsgálja az európai és a romániai nyilvános statisztikai adatok másodelemzése alapján. Az elemzés két feltételezés megerősítését célozza: 1. a digitális technológia széles körű elterjedése ellenére a digitális egyenlőtlenségek nem egyenlítődnek ki; 2. a hagyományos és a digitális tőke megoszlása hasonló tendenciákat követ. A feltételezéseket a vizsgálat igazolta. Az elmúlt tíz évben Romániában az internethasználók aránya folyamatosan nőtt, azonban a másodlagos és harmadlagos digitális megosztottság tekintetében Románia és az európai országok között jelentős szakadék húzódik.

Kulcsszavak: digitális egyenlötlenségek, digitális tőke, digitális technológia diffúziója, Románia, Közép-Kelet-Európa

\section{Szerzői útmutató}

Tőkés Gyöngyvér Erika, Sapientia Erdélyi Magyar Tudományegyetem https://orcid.org/0000-0003-0973-1742

Így hivatkozzon erre a cikkre:

Tőkés Gyöngyvér Erika. „Digitális egyenlőtlenségek és digitális tőkemegoszlás Romániában”.

Információs Társadalom XXI, 3. szám (2021): 109-125.

\section{—https://dx.doi.org/10.22503/inftars.XXI.}

a Creative Commons Nevezd meg! - Ne add el! - Így add tovább! 4.0

Nemzetközi Licenc feltételeinek megfelelően használhatók 


\section{Digital inequalities and distribution of digital capital in Romania}

The study examines the situation of digital inequalities and the distribution of digital capital in Romania, based on a secondary analysis of European and Romanian public statistics. The analysis aims to verify two hypotheses: 1 . despite the widespread diffusion of digital technology digital inequalities are not levelling out; 2. the distribution of traditional and digital capital follows similar trends. In the course of the study, the assumptions proved to be true. Over the last decade, Romania has witnessed a steady increase in the share of internet users, but there is a significant gap between Romania and European countries in terms of second and third level digital divides.

Keywords: digital inequalities, digital capital, diffusion of digital technology, Romania, Central-Eastern-Europe 


\section{Bevezető}

Az internet széles körü elterjedése lendületet adott a techno-optimista nézetnek (Ragnedda 2017), mely szerint a korlátlanul elérhető internetes tartalom esélyegyenlőséget teremt az információs társadalom tagjai számára, hogy életkörülményeiket és életminőségüket egyéni, társadalmi, kulturális, gazdasági vagy politikai aspektusból egyaránt javítani tudják (Norris 2001; McKeown 2016). Ez a gondolat nem új keletű, hiszen a hagyományos tömegmédia elterjedése hasonló várakozásokat keltett, azonban az optimizmus megalapozatlannak bizonyult (Tichenor, Donohue és Olien 1970; Viswanath és Finnegan 1996). Az újraéledő techno-optimista nézetet az internet társadalmi hatását vizsgáló kutatások nem támasztják alá (Hargittai 2002; van Dijk 2005, 2008; Witte és Mannon 2010; Helsper 2010, 2012; Fizeșan 2012; van Deursen és van Dijk 2014; ven Deursen és Helsper 2015, 2018).

A digitális technológia társadalmi befogadását vizsgáló kutatások a digitális egyenlőtlenségek három formáját különböztetik meg: a hozzáférés (elsődleges), a hozzáértés (másodlagos) és a hasznosság egyenlőtlenségét (harmadlagos digitális szakadék). A kutatások alapján a digitális egyenlőtlenségek a hagyományos rétegződési feltételeket követik (Ragnedda 2017, 2018, 2019; Park 2018; Ragnedda és Ruiu 2020; van Deursen és van Dijk 2015; van Dijk 2005, 2008).

Bizonyos szerzők a digitális tőkét önálló rétegképző tényezőnek tekintik (Ragnedda 2017, 2018, 2019; Ragnedda és Ruiu 2020). Ez olyan digitális tudásra, tapasztalatra, kompetenciára, műveltségre, eszközökhöz való hozzáférésre vonatkozik, amely konverziós stratégiák alkalmazásával hagyományos tőkeformákká alakítható (Ragnedda 2017; van Deursen és van Dijk 2015).

A tudásszakadék hipotézise (Tichenor, Donohue és Olien 1970) és a bourdieui tőkeelmélet (Bourdieu 1997[1986]) alátámasztja, hogy a különböző tőkeformák vonzzák egymást. Ennek megfelelően a hagyományos tőkeformákkal (gazdasági, kulturális, politikai, társadalmi, egyéni) való rendelkezés növeli a digitális tőke megszerzésének esélyeit (Ragnedda 2017; Ragnedda és Ruiu 2020). A digitális tőke egyenlőtlen megoszlása a társadalmi egyenlőtlenségek újratermelődését erősíti (Ragnedda 2017; Ragnedda és Ruiu 2020).

Jelen tanulmányban a romániai digitális egyenlőtlenségek helyzetének és a digitális tőke társadalmi megoszlásának elemzésére kerül sor, az Európai Unió statisztikai szolgáltatása, az Eurostat és a romániai Nemzeti Statisztikai Hivatal által létrehozott Tempo Online adatbázis 2019-es adatainak másodelemzése alapján. A vizsgálódás társadalmi szintű, és két feltételezés mentén halad:

- a digitális technológia széles körű romániai elterjedésével a digitális egyenlőtlenségek fennmaradnak (Ștefăniță és Ivan 2018; Európai Bizottság 2017; Balea 2016; Fizeșan 2012; Livingstone és Helsper 2010; Hargittai 2010; Tufă 2010; Molnár 2002);

- a digitális tőke megoszlása a hagyományos tőkeformák megoszlásához hasonló tendenciát követ (Ragnedda és Ruiu 2020; van Deursen és van Dijk 2014; Molnár 2002).

A tanulmány a digitális megosztottság és a digitális tőke fogalmainak áttekintésével kezdődik, majd a digitális egyenlőtlenségek és a digitális tőkemegoszlás romániai 
helyzetének elemzésével folytatódik az elmúlt tíz év vonatkozásában. A tanulmány az adatok értelmezésével és a romániai digitális egyenlőtlenségek feloldását elősegítő javaslatok összefoglalásával zárul.

\section{Digitális megosztottság}

Az internethasználat korai kutatásai az innovációterjedés felől közelítik meg az internet társadalmi adaptációját (André et al. 2010). Az internet a magas és közepes jövedelmű országokban hamarabb elterjedt, míg az alacsony jövedelmű országok digitális felzárkózása jelenleg sem történt meg (André et al. 2010; DESI 2019). Az internet elterjedésének egyik leggyakrabban alkalmazott mérőszáma az internetet nem használók arányának alakulása, amely az alacsony jövedelmű országokban még mindig magas (Eurostat 2019).

Rogers (1995) szerint az internet elterjedése diffúziós szakaszokban történik. Az első felhasználókat újítóknak nevezik (a népesség 2,5 százaléka), akikhez a korai adaptálók csatlakoznak (a népesség 13,5 százaléka). Amikor már látható az innováció hasznossága, a korai többség (a népesség 34 százaléka), majd a késői többség (a népesség 34 százaléka) is alkalmazkodik. Utoljára a lemaradók zárkóznak fel (a népesség 16 százaléka), akik számára az innováció befogadásának nincs kockázata (Dessewffy és Galácz 2003).

Az internet társadalmi befogadását vizsgáló kezdeti kutatásokban a digitális szakadék fogalmát használták, mely szerint az internethozzáférés tekintetében a társadalom két nagy csoportra osztható: az internethez hozzáférőkre és a hozzá nem férőkre. A vizsgálatok hamar rámutattak arra, hogy az úgynevezett digitális szakadék jelensége többdimenziós, hiszen nem minden egyén képes a saját hasznára fordítani a hozzáférés adta lehetőségeket és előnyöket (Ragnedda 2019). A kutatók a digitális szakadék fogalmát a digitális megosztottságra váltották. Az elsődleges digitális megosztottság fogalmát Hargittai Eszter vezeti be (Hargittai 2002), amely alatt az internetet használókat és nem használókat különbözteti meg. Ugyanakkor az internethasználók között lényeges különbségek észlelhetők a használat minősége, a digitális képességek szintje és az internethasználat iránti elkötelezettség függvényében. Az internet használatának minőségi különbségeit másodlagos digitális megosztottságnak nevezték el (Scheerder, van Deursen és van Dijk 2017; Hargittai 2002, 2007). Jelenleg a harmadlagos digitális megosztottság kutatása zajlik (Ragnedda 2018, 2019; van Deursen és Helsper 2017; van Deursen és Helsper 2015; Helsper 2012). Az internethasználat mintáinak lényeges eltérései tapasztalhatók a társadalmi csoportok között, amennyiben a figyelem az internethasználatnak a társadalmi, gazdasági, politikai, kulturális vagy egyéni téren megvalósuló hasznosságára irányul (van Deursen és Helsper 2017; van Deursen és Helsper 2015; Helsper 2012; van Dijk, 2005).

A kutatások a digitális megosztottságot befolyásoló szociodemográfiai sajátosságok között az életkort, a nemet, az iskolai végzettséget, a foglalkozást, a jövedelmet, a lakóhelyet, az egészségügyi állapotot és a digitális kompetenciaszintet említik (Ștefăniță és Ivan 2018; van Deursen és Helsper 2015; van Deursen és van Dijk 2014).

Van Deursen és Helsper (2015) igazolták, hogy a digitális tevékenységek abban az esetben vezetnek az offline életben is kézzelfogható haszonhoz, amennyiben a 
felhasználók a hagyományos egyenlőtlenségek területein jelentős erőforrásokkal rendelkeznek. Véleményük szerint a hasonló digitális képességekkel és jártassággal rendelkező felhasználók digitális térben folytatott tevékenységeinek hasznossága a rendelkezésre álló hagyományos tőkék függvényében alakul. Tehát a digitális megosztottság vizsgálata a társadalmi egyenlőtlenségek számbavétele nélkül lehetetlen és értelmetlen.

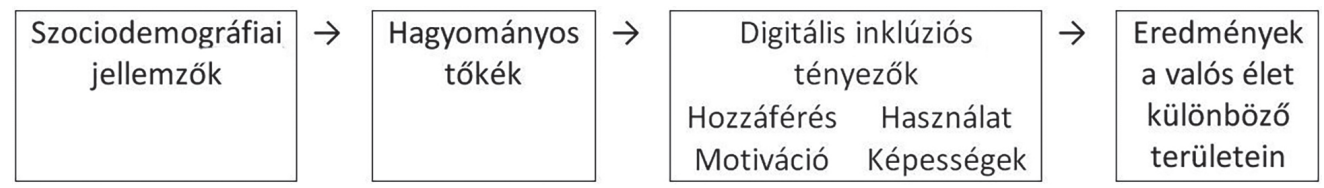

1. ábra: Az egyenlőtlenségek újratermelődésének modellje az információs társadalomban (van Deursen és Helsper 2015 alapján, saját szerkesztés)

Molnár (2002) az internet elterjedésének diffúziós szakaszait összekapcsolta a digitális megosztottsággal. Véleménye szerint az egymást követő diffúziós szakaszokban a digitális megosztottság újabb aspektusai kerülnek előtérbe, ezért a telítődés időszakában sem érhető el a teljes egyenlőség. Az innovációk elterjedésének Saren-féle modellje szerint (Saren 1984) az innovációk meghonosodását a hasznosulásuk követi. Ilyen értelemben Molnár integrált modellje (2002) új adaptációs szakasszal egészíthető ki, éspedig az internet hasznosulási szakaszával, amelyhez a harmadlagos digitális megosztottság rendelhető.

\begin{tabular}{|c|c|c|c|c|}
\hline $\begin{array}{c}\text { Adaptációs } \\
\text { szakasz }\end{array}$ & Típusa & Megnevezése & Tartalma & $\begin{array}{l}\text { Befolyásoló } \\
\text { tényezők }\end{array}$ \\
\hline $\begin{array}{l}\text { korai } \\
\text { adaptáció }\end{array}$ & $\begin{array}{l}\text { hozzáférési } \\
\text { megosztottság }\end{array}$ & $\begin{array}{l}\text { digitális } \\
\text { szakadék }\end{array}$ & $\begin{array}{l}\text { hozzáférő és } \\
\text { nem hozzáférő } \\
\text { közötti különb- } \\
\text { séget írja le }\end{array}$ & $\begin{array}{l}\text { életkor, nem, } \\
\text { iskolai végzett- } \\
\text { ség, jövedelem, } \\
\text { lakóhely }\end{array}$ \\
\hline $\begin{array}{l}\text { neki- } \\
\text { rugaszkodás }\end{array}$ & $\begin{array}{l}\text { használati meg- } \\
\text { osztottság }\end{array}$ & $\begin{array}{l}\text { elsődleges di- } \\
\text { gitális megosz- } \\
\text { tottság }\end{array}$ & $\begin{array}{l}\text { használó és nem } \\
\text { használó közötti } \\
\text { különbséget } \\
\text { írja le }\end{array}$ & $\begin{array}{l}\text { életkor, iskolai } \\
\text { végzettség, fog- } \\
\text { lalkozás }\end{array}$ \\
\hline telítődés & $\begin{array}{l}\text { a használat } \\
\text { minőségéből } \\
\text { fakadó megosz- } \\
\text { tottság }\end{array}$ & $\begin{array}{l}\text { másodlagos } \\
\text { digitális megosz- } \\
\text { tottság }\end{array}$ & $\begin{array}{l}\text { használó és } \\
\text { használó közötti } \\
\text { különbséget } \\
\text { írja le }\end{array}$ & $\begin{array}{l}\text { életkor, nem, } \\
\text { iskolai végzett- } \\
\text { ség, jövedelem, } \\
\text { digitális tapasz- } \\
\text { talat }\end{array}$ \\
\hline hasznosulás & $\begin{array}{l}\text { a használat } \\
\text { eredményes- } \\
\text { ségéből fakadó } \\
\text { megosztottság }\end{array}$ & $\begin{array}{l}\text { harmadlagos } \\
\text { digitális megosz- } \\
\text { tottság }\end{array}$ & $\begin{array}{l}\text { hasonló digitális } \\
\text { kompetenciájú } \\
\text { felhasználók } \\
\text { közötti viszony- } \\
\text { rendszert írja le }\end{array}$ & $\begin{array}{l}\text { életkor, nem, is- } \\
\text { kolai végzettség } \\
\text { (van Deursen és } \\
\text { Helsper 2015) }\end{array}$ \\
\hline
\end{tabular}

1. táblázat: Az internet adaptációja és a digitális megosztottság integrált modellje (Molnár 2002 alapján, saját összeállítás) 


\section{Digitális tőke}

Ragnedda és Ruiu (2020) a digitális tőkét a 21. század új erőforrásaként határozzák meg. A digitális megosztottság szakirodalmában a digitális tőke a hagyományos tőkéket áthidaló tőkeforma, melynek felhalmozása hozzájárul a hagyományos tőkeformák szerinti előnyös helyzet megerősítéséhez vagy kihangsúlyozásához. A felhalmozott digitális tőke befolyásolja a másodlagos digitális egyenlőtlenségeket az online térben és a harmadlagos digitális egyenlőtlenségeket az offline térben (Ragnedda 2018; van Deursen és Helsper 2015; Helsper 2012).

A digitális tőke leginkább a kulturális tőkéhez hasonlít, hiszen "testre szabott" és bensővé tételt feltételez. A digitális tőke felhalmozását az elsajátítási folyamat előzi meg, ez pedig gazdasági ráfordításba és tanulási időbe kerül. A digitális tőke megszerzésének elsődleges feltétele a digitális eszközök beszerzéséhez szükséges gazdasági tőke. Az időt a beruházónak személyesen kell ráfordítani, a képviseleti elv kizárt. A Bourdieu-féle (1997[1986]) analógiát használva, aki a digitális tőke megszerzésén dolgozik, az a személyével fizet, és a tanulási folyamat során időt áldoz, kudarcokat és nehézséget él meg. Ugyanakkor az inkorporált digitális tőke habitussá, szokássá alakul. A felhalmozott digitális tőke különlegességi értéket képvisel és a tőkeelosztási szerkezetben előnyös helyzetet teremt, amelyből extraprofitot lehet szerezni vagy a munkaerőpiacon pénzre lehet váltani (ITU 2018).

A digitális tőke átadására a szocializációs folyamat során mindeddig nem került sor, hiszen a jellegzetes tőkék családon belüli átadásának előfeltétele a tőkeformák felhalmozása. A digitális tőke családon belüli átadásában jelenleg a fordított szocializáció érvényesül. Az információs társadalmat megelőzően a szülők voltak a társadalmi tudás és a releváns élettapasztalat átadásának forrásai. Az információs társadalomban a helyzet némileg felborul, és a technológiai újdonságokra fogékony fiatal korcsoportok lépéselőnybe kerülnek a társadalmilag hasznosítható digitális tapasztalatszerzés terén. A fiatalok egymástól tanulják el a technológiahasználatot, ezen a téren a szülők és nagyszülők tanítóivá válnak (Csepeli 2003). A digitális tőke a fiatal életkori csoportok erőforrása, melynek birtoklása identitásukkal szervesen összekapcsolódik és hitelképességet kölcsönöz számukra (Bourdieu 1997[1986]).

Ragnedda és Ruiu (2020) szerint a digitális tőke a birtokolt tőkék összetételét gazdagítja, mennyisége pedig a társadalmi szerkezetbéli pozíciót befolyásolja. A modernitás korában a társadalom tagjai a rendelkezésükre álló úgynevezett hagyományos tőkéket mozgósították a társadalomban elfoglalt helyzetük és presztízsük javításához. Az információs társadalomban a digitális tőke megfelelő befektetése az élet különböző területein a hagyományos tőkék gyarapítását segíti elő, tehát társadalmi erőforrássá válik (Ragnedda 2018). Csak a társadalmilag elismert tőke alkalmas a konverzióra. Ragnedda és Ruiu (2020) a digitális tőke előnyös társadalmi reprezentációjára és konverziós potenciájára világítanak rá, a digitális mezőnyre jellemző stratégiák betartásával. A digitális tőke időben felhalmozható, belsővé tett képességek és rátermettség, valamint a rendelkezésre álló digitális eszközök és alkalmazások formájában.

Ragnedda (2018) szerint a digitális tőke hidat képez az online és az offline életesélyek között. A digitális tőke lehetővé teszi az offline tevékenységek átirányítását a 
digitális térbe, és hozzájárul az offline hasznok újratermeléséhez az élet különböző területein. A digitális tőke különlegessége, hogy működtetéséhez a hagyományos tőkeformák birtoklása szükséges. Amennyiben valaki nem rendelkezik az erőforrások hagyományos formáival, a digitális tőke nem segíti a további tőkeakkumulációt (van Deursen és Helsper 2015).

Ragnedda (2018) négy forgatókönyvet állít fel a digitális és a hagyományos tőkeformák kapcsolatáról.

\begin{tabular}{|c|c|c|c|}
\hline \multirow[t]{3}{*}{$\begin{array}{c}\text { előnyös } \\
\text { forgatókönyv: magas } \\
\text { DT, magas } 5 \mathrm{HT} \\
\end{array}$} & & & \\
\hline & $\begin{array}{c}\text { köztes forgatókönyv } \\
\text { (a): alacsony DT, } \\
\text { magas 5HT }\end{array}$ & $\begin{array}{c}\text { köztes forgatókönyv } \\
\text { (b): magas DT, } \\
\text { alacsony 5HT }\end{array}$ & \\
\hline & & & $\begin{array}{l}\text { hátrányos } \\
\text { forgatókönyv: } \\
\text { alacsony DT, } \\
\text { alacsony 5HT }\end{array}$ \\
\hline
\end{tabular}

2. ábra: A digitális és a hagyományos tőkék kapcsolata

(Ragnedda 2018 alapján, saját szerkesztés)

Az előnyös forgatókönyv esetében a digitális térben való jártassághoz (másodlagos digitális egyenlőtlenség) a konverziós képesség társul (harmadlagos digitális egyenlőtlenség). Ebben az esetben az egyén a társadalom valamely előnyös pozícióját tölti be (Ragnedda 2018). A hátrányos forgatókönyv esetén az egyén hátrányos társadalmi helyzete tovább fokozódik, és mind a társadalomban mind a digitális világban lemaradó helyzetbe kerül (Ragnedda 2018).

Ragnedda (2018) két köztes forgatókönyvet is elkülönít. Az első (a) esetében az egyén nem érdekelt vagy nem képes életesélyeit tovább növelni a digitális tőke felhalmozásával. Ez a forgatókönyv főleg idősebb életkorúakra jellemző. A második köztes forgatókönyv (b) alapján a hagyományos tőkét nélkülöző egyén digitális tőkéjét nem képes konvertálni. A két köztes forgatókönyvben a digitális és a hagyományos tőkék kiegyensúlyozatlansága nem kedvez újabb erőforrások felhalmozásának, és nem vezet a társadalmi helyzet javításához. Ennek némileg ellentmond Park (2018) forgatókönyve a társadalmi és a digitális kirekesztettség kapcsolatáról. Szerinte (Park 2018) a társadalmilag kirekesztett, azonban digitálisan képzett személyek a társadalmi hátrányaikat képesek leküzdeni bizonyos határok között.

A digitális egyenlőtlenségek jelentős kérdése a digitálisnak tekintett korosztályok digitális tőkeellátottságának későbbi alakulása. A fiatalok és gyerekek digitális müveltségét vizsgáló kutatások (EU Kids Online 2006-2014, Net Children Go Mobile 2014, Digital Literacy and Multimodal Practices of Young Children 2014-2020) a felnőtt lakossághoz hasonló digitális megosztottságra utalnak (Balea 2016; Fizeșan 2012; Livingstone és Helsper 2010). A gyerekek és fiatalok digitális rétegzettségének hátterében olyan magyarázó tényezők állnak, mint a családok kulturális tőkéje, a családok anyagi helyzete, a gyerekek és fiatalok társas és oktatási környezete, va- 
lamint olyan egyéni jellemzők, mint a gyerek érdeklődése, kíváncsisága, kitartása, online tapasztalata és önbizalma (Livingstone és Helsper 2013; Barbovschi és Balea 2013; Velicu, Balea és Barbovschi 2019). Az ITU (2018) jelentése alapján a digitális egyenlőtlenség nem generációs kérdés. A digitális tőke valójában a társadalmi tagolódás egy újabb ismérvének tekinthető, amely a hagyományos tőkeformákkal összefonódva újratermeli az érvényesülő társadalmi egyenlőtlenségek viszonyrendszerét.

\section{Digitális megosztottság Romániában}

Az Európai Unió országai között az információs társadalom mutatói alapján Románia hátrányos helyzetben van (Niță 2011; DESI 2019). Összevetve a szomszédos közép-kelet-európai országokkal, Románia csak Bulgáriát előzte meg az internetet valaha használó lakosság aránya tekintetében.

Az Eurostat 2019-es adatai alapján a romániai háztartások 84 százaléka hozzáfért az internethez, és ebből 82 százalék széles sávú internetet használt. 2019-ben az internetet soha nem használók romániai aránya 18 százalék volt, amely alapján Románia az Európai Unió országai közül Görögországot, Bulgáriát és Portugáliát előzte meg. Az Európai Unión belüli digitális megosztottság az északi és déli, valamint a nyugati és keleti tengely mentén húzódik. Románia az Európai Unió szempontjából délen és keleten helyezkedik el, így mindkét tengely mentén a digitálisan lemaradt régiókba sorolható (van Dijk 2008).

Ștefăniță és Ivan (2018) felhívják a figyelmet Románia országon belüli regionális szintű digitális megosztottságára; az ország fejlettebb régióiban (nyugati és észak-nyugati régió, főváros és környéke) magasabb az internethasználók aránya a fejletlen régióhoz viszonyítva (a déli és a keleti régiók). Szintén jellemző a nagyvárosi, valamint a kisvárosi és vidéki térségek közötti különbség az internethasználók arányát tekintve, hiszen vidéken a lakosság idősebb, alacsonyabb az iskolai végzettség $^{1}$ és a jövedelem szintje ${ }^{2}$, amelyek negatívan hatnak az internet adaptációjára. Az elmúlt tíz év idősoros adatai a vidéki lakosság digitális felzárkózását igazolják, ennek ellenére 2019-ben a nagyvárosi lakosság 62 százaléka, míg a vidéki lakosság csak 40 százaléka internezett naponta (Tempo Online 2019). A vidéki lakosság digitális felzárkózása az okostelefonok és a mobilinternet elterjedése után vált látványossá, amikor a személyes eszköztárban már házias telefonkészülék internetezésre is alkalmassá vált.

Romániában az elmúlt tíz évben a fiatal internethasználók aránya magasabb volt a felnőtt és az idősebb korosztályokhoz viszonyítva (Tufă 2010), azonban a fiatalabb korosztályok internethasználatára is a belső rétegzettség jellemző. Az idős korcsoportok felzárkózása is elkezdődött, hiszen a 65-74 évesek körében az elmúlt tíz évben tízszeresére nőtt az internethasználók aránya (45 százalékra).

\footnotetext{
${ }^{1}$ A felsőfokú végzettségűek aránya városon 31,4 százalék, kisvárosi környezetben 12,2 százalék, vidéki környezetben 5,3 százalék (Eurostat 2019).

${ }^{2}$ Az éves átlagjövedelem városon 28.836 RON, míg vidéki környezetben 15.027 RON (Eurostat 2019).
} 
Ștefăniță és Ivan (2018) rámutatnak arra, hogy az elmúlt tíz évben a férfiak magasabb arányban váltak internethasználókká a nőkhöz viszonyítva, azonban ez a különbség körülbelül 5 százaléknál állandósult. A magasabb életkor és az alacsonyabb iskolai végzettség a nők hátrányát fokozza. A digitális tevékenységek tekintetében a nők főleg kommunikációra, míg a férfiak információ keresésére használják az internetet.

Az elmúlt tíz évben a felsőfokú és középfokú iskolai végzettségűek körében a felhasználók aránya magasabb volt az elemi és általános iskolai végzettségűekhez képest. 2019-ben napi szinten internezett az elemi iskolai végzettségűek 67 százaléka, az általános iskolai végzettségűek 71 százaléka, a középfokú végzettségűek 80 százaléka, az egyetemi végzettségűek 93 százaléka (Tempo Online 2019). Ennek magyarázta, hogy a felsőfokú vagy középszintű iskolai végzettséggel rendelkező felhasználók nagyobb arányban dolgoztak olyan munkahelyen, ahol az internethasználat a munkavégzés része. Az üzleti (95 százalék) és az infokommunikációs (94 százalék) szolgáltatások terén, valamint a közigazgatásban, az oktatásban és az egészségügyben (91 százalék), továbbá a banki szolgáltatások (90 százalék) terén dolgozók többsége internethasználó (Eurostat 2020).

Az egyének jövedelmi szintje szintén összefügg az internethasználattal. Míg az első jövedelmi kvartilisbe tartozó lakosság 57 százaléka, addig a negyedik kvartilisbe tartozó lakosság 90 százaléka internethasználó (Eurostat 2020).

2019-re a romániai lakosság késői többsége is felzárkózott az internethasználathoz, és jelenleg a lemaradók felzárkóztatására van szükség. A digitális kirekesztettségtől leginkább fenyegetett csoportok az idősek, az alacsonyabb iskolai végzettséggel és alacsony jövedelemmel rendelkezők (Niță 2011).

Az Eurostat (2019) és a Tempo Online (2019) által közölt statisztikai adatok alapján a Romániára jellemző másodlagos és harmadlagos digitális megosztottságnak néhány jellemzője követhető nyomon.

Az online csatornákon keresztüli munkahelykeresés a digitális tevékenységek gazdasági hasznához tartozik. Az Eurostat (2019) adatai alapján a romániai felhasználók 5 százaléka keresett állást online módon. Az EU28 országaiban a lakosság 16 százaléka használta az internetet álláskeresésre. Nem áll rendelkezésre sem európai sem romániai adat arról, hogy az online munkakeresők milyen arányban jutottak számukra kielégító álláshoz, amely a harmadlagos digitális megosztottságra világítana rá. A szakmai közösségi oldalakon a romániai felhasználók 4 százaléka, míg az európai lakosságnak 11 százaléka volt jelen (Eurostat 2017).

Az online platformok közvetítésével történő hatékony pénzfelhasználás a harmadlagos digitális megosztottság mutatója. Erre utalnak az online módon olcsóbban vásárolt termékek és szolgáltatások, továbbá a termékek és szolgáltatások online értékesítése. A romániai felhasználók 33 százaléka a termékek és szolgáltatások áráról szokott online módon érdeklődni, míg az európai felhasználók 66 százaléka teszi ugyanezt (Eurostat 2019). A romániai felhasználók 3 százaléka értékesített termékeket és szolgáltatásokat online felületeken, az európai lakosságnak pedig 18 százaléka járt el hasonló módon. Nincs adat arról, hogy a romániai felhasználók vásároltak-e olcsóbban termékeket és szolgáltatásokat, azonban tudjuk, hogy az utóbbi évben az online vásárlás lehetőségét a romániai felhasználók mindössze 23 százaléka vette 
igénybe. Az európai felhasználók 60 százalékára jellemző az online vásárlás. A romániai felhasználók 8 százaléka (Globalfindex 2017)³, míg az európai felhasználók 55 százaléka bankolt online (Eurostat 2019).

Részben a gazdasági, részben az oktatási területhez tartozik a képzésekről történő online tájékozódás, valamint az online tanfolyamokon való részvétel. A tájékozódás képessége a másodlagos, míg a részvétel a harmadlagos digitális megosztottság mutatója. Az Eurostat (2019) adatai alapján az elmúlt évben a romániai felhasználók 3 százaléka, míg az európai felhasználók 8 százaléka vett részt online tanfolyamon. Tananyagot a romániai felhasználók 12 százaléka, az európai felhasználók 15 százaléka töltött le.

A digitális tevékenységeknek számos társadalmi előnye van. A felhasználók könynyebben lépnek kapcsolatba egymással, rokonaikkal és barátaikkal. Az új ismerősök szerzése főleg a fiatalabb felhasználókra jellemző. Az Eurostat (2019) adataiból az derül ki, hogy az aktív közösségi médiahasználat a romániai felhasználók 60 százalékára jellemző, míg az európai felhasználóknak csak 54 százaléka vesz részt a közösségi médiatevékenységekben. Ez viszont a szórakozásra és időtöltésre irányított internethasználatot hangsúlyozza a hasznos internetfelhasználás ellenében (Ștefăniță és Ivan 2018).

A digitális tér a politikai vélemények kinyilvánítására és a politikai megmozdulásokhoz való csatlakozásra is lehetőséget nyújt. Az Eurostat szerint 2019-ben a romániai felhasználók 8 százaléka, míg az európai felhasználók 11 százaléka osztotta meg politikai véleményét az interneten. A romániai felhasználóknak szintén 8 százaléka, az európai felhasználók 16 százaléka vett részt valamilyen online politikai kezdeményezésben. Online politikai szavazáson vagy nyilvános véleményezésen a romániai felhasználók 3 százaléka, míg az európai felhasználók 10 százaléka vett részt. Nincs statisztikai adat a romániai internethasználóknak a politikai pártokhoz vagy szervezetekhez való online csatlakozásáról.

Ragnedda (2019) a közszolgálati hasznok területéhez sorolja a hatóságokkal fenntartott kommunikációt és az egészségügyi rendszer igénybevételét az online térben. A hatósági ügyintézés lehetőségeiről a romániai felhasználók 9 százaléka szerzett adatokat, 12 százalék pedig kapcsolatba is lépett a hatóságokkal a digitális térben. Ugyanezeket a tevékenységeket az európai felhasználók 44, illetve 53 százaléka végezte. Online egészségügyi ismereteket a romániai felhasználók 31 százaléka keresett, ugyanez az európai felhasználók 53 százalékára igaz. Az egészségügyi szolgáltatások online elérése a romániai felhasználók 5 százalékát, az európai felhasználóknak pedig 18 százalékát jellemezte (Eurostat 2019). Az európai átlag alatti eredményeket Romániában az online közszolgáltatások hiánya magyarázza (DESI 2019).

Személyi téren a digitális tevékenységek számos előnnyel járnak. A romániai felhasználóknak 40, az európai felhasználóknak 62 százaléka olvasott híreket, a romániai felhasználók 49 százaléka és az európai felhasználók 52 százaléka folytatott videohívásokat, a romániai felhasználók 15 százaléka és az európai felhasználók 29

\footnotetext{
${ }^{3}$ A román népesség 57,8 százaléka rendelkezett 2018-ban számlaszámmal (https://globalfindex.worldbank.org/), az online bankoláshoz pedig alapfeltétel a banki szolgáltatások igénybevétele.
} 
százaléka osztott meg saját tartalmakat online térben. A kreatív internethasználat alacsonyabb szintje a romániai felhasználók alacsony digitális kompetenciaszintjével köthető össze (Eurostat 2019).

Az Európai Bizottság 2015 óta évente követi az EU-tagországok digitális versenyképességét a digitális gazdaság és társadalom fejlettségét mérő DESI-index kiszámításával (DESI 2019). A DESI index öt dimenziót vesz figyelembe: a hálózati összekapcsoltságot, a humán tőkét, az internetes szolgáltatások használatát, a digitális technológiák integráltságát és a digitális közszolgáltatásokat. A DESI index alapján Románia 2019-ben a 28 országból a 26. helyen szerepelt. Az ország a hálózati összekapcsoltság tekintetében teljesített jól, viszont az összes többi DESI-mutató alapján az utolsó helyeket foglalta el.

Összességében, az Európai Unió szintjén, a romániai felhasználók lényegesen lemaradnak gazdasági, oktatási és politikai téren az értékes digitális információk megtalálása és a hasznos digitális tevékenységek végzése tekintetében. A romániai felhasználók a digitális jelenlét hasznát társadalmi és egyéni téren tapasztalják.

\section{Digitális tőkemegoszlás Romániában}

A digitális tőke az információs társadalom új tőkéje, amelynek hiánya a digitális átalakulás keretei között a társadalmi részvételt hátrányosan befolyásolja (Ștefăniță és Ivan 2018; DESI 2019). A digitális tőke többet jelent a digitális kompetenciánál, azonban az elérhető statisztikai adatok a digitális kompetenciára korlátozódnak.

Az Eurostat 2019-es adatai szerint a romániai felhasználók 10 százaléka alapszint feletti, 21 százaléka alapszintű és 43 százaléka alapszint alatti digitális kompetenciával rendelkezett. A romániai lakosság 26 százaléka digitális analfabéta, ebből 18 százalék soha nem is internetezett. Románia hátránya egyértelmű, hiszen az Európai Unió 28 országában a lakosság 33 százaléka alapszint feletti, 25 százaléka alapszintű és 28 százaléka alapszint alatti digitális kompetenciáról számolt be.

\begin{tabular}{|l|l|l|l|l|l|l|}
\hline \multirow{2}{*}{ Életkor } & \multicolumn{2}{|c|}{$\begin{array}{c}\text { Alapszint alatti } \\
\text { digitális kompetencia }\end{array}$} & \multicolumn{2}{c|}{$\begin{array}{c}\text { Alapszintü digitális } \\
\text { kompetencia }\end{array}$} & \multicolumn{2}{c|}{$\begin{array}{c}\text { Alapszint feletti } \\
\text { digitális kompetencia }\end{array}$} \\
\cline { 2 - 8 } & Románia & \multicolumn{1}{|c|}{ EU28 } & Románia & EU28 & Románia & EU28 \\
\hline 16-24 év & 39 & 16 & 34 & 23 & 22 & 59 \\
\hline 25-34 év & 49 & 21 & 26 & 26 & 15 & 50 \\
\hline 35-44 év & 49 & 27 & 25 & 28 & 13 & 39 \\
\hline 45-54 év & 49 & 32 & 19 & 28 & 7 & 30 \\
\hline 55-64 év & 41 & 35 & 13 & 25 & 5 & 18 \\
\hline 65-74 év & 24 & 32 & 7 & 19 & 1 & 8 \\
\hline
\end{tabular}

2. táblázat: A digitális műveltségi szint megoszlása életkori csoportok szerint Romániában és az EU28 országok átlaga (\%) (Eurostat 2019 alapján) 
Ștefăniță és Ivan (2018) hangsúlyozzák a fiatalok előnyét a felnőtt és idős korcsoportokkal szemben a digitális kompetenciaszint szempontjából, de körükben is 40-50 százalék digitálisan szegénynek nevezhető (ITU 2018). A korábban már megemlített közép-kelet-európai országokban és általában az EU28 országaiban szintén a fiatal korosztályok előnye figyelhető meg a digitális tőkemegoszlást illetően, viszont hozzájuk viszonyítva a romániai fiatalok lemaradó csoportot alkotnak (Eurostat 2019).

A magasabb szintű iskolai végzettség növeli annak valószínűségét, hogy a felhasználó alapszint feletti digitális kompetenciával rendelkezik (lásd 3. táblázat), azonban a romániai felsőfokú iskolai végzettségűek egyharmadára szintén az alapszint alatti digitális kompetencia jellemző. Az alapfokú iskolai végzettségűek között a legmagasabb az internet-hozzáférést nélkülözők aránya (Eurostat 2019). A digitális kompetenciával való rendelkezés nemi megoszlása nem hangsúlyos, de a statisztikai adatokból felismerhető a tendencia, miszerint a magasabb iskolai végzettségű férfiak nagyobb arányban rendelkeznek alapszint feletti digitális kompetenciával, míg az alacsonyabb iskolai végzettségű felhasználók között a nők rendelkeznek alacsonyabb digitális kompetenciaszinttel (Eurostat 2019).

\begin{tabular}{|c|c|c|c|c|c|c|c|c|c|}
\hline \multirow{2}{*}{$\begin{array}{l}\text { Iskolai } \\
\text { végzettség/ } \\
\text { Ország }\end{array}$} & \multicolumn{3}{|c|}{$\begin{array}{c}\text { Alapszint alatti } \\
\text { digitális kompetencia }\end{array}$} & \multicolumn{3}{|c|}{$\begin{array}{c}\text { Alapszintü digitális kom- } \\
\text { petencia }\end{array}$} & \multicolumn{3}{|c|}{$\begin{array}{c}\text { Alapszint feletti } \\
\text { digitális kompetencia }\end{array}$} \\
\hline & $\begin{array}{l}\text { Alap- } \\
\text { fokú }\end{array}$ & $\begin{array}{l}\text { Közép- } \\
\text { fokú }\end{array}$ & $\begin{array}{l}\text { Felsö- } \\
\text { fokú }\end{array}$ & $\begin{array}{l}\text { Alap- } \\
\text { fokú }\end{array}$ & $\begin{array}{l}\text { Közép- } \\
\text { fokú }\end{array}$ & $\begin{array}{l}\text { Felsö- } \\
\text { fokú }\end{array}$ & $\begin{array}{l}\text { Alap- } \\
\text { fokú }\end{array}$ & $\begin{array}{l}\text { Közép- } \\
\text { fokú }\end{array}$ & $\begin{array}{l}\text { Felsö- } \\
\text { fokú }\end{array}$ \\
\hline Románia & 33 & 50 & 29 & 13 & 21 & 31 & 5 & 6 & 36 \\
\hline Bulgária & 28 & 46 & 28 & 6 & 16 & 35 & 4 & 7 & 29 \\
\hline Magyarország & 31 & 37 & 16 & 13 & 25 & 27 & 10 & 20 & 52 \\
\hline Lengyelország & 21 & 44 & 20 & 18 & 20 & 34 & 22 & 12 & 44 \\
\hline Csehország & 24 & 29 & 8 & 21 & 38 & 40 & 26 & 18 & 51 \\
\hline Szlovákia & 23 & 34 & 15 & 13 & 28 & 30 & 36 & 47 & 52 \\
\hline EU28 & 37 & 32 & 12 & 16 & 28 & 28 & 16 & 28 & 57 \\
\hline
\end{tabular}

3. táblázat: A digitális kompetenciaszint megoszlása iskolai végzettség szerint Romániában és öt közép-kelet-európai országban (\%) (Eurostat 2019 alapján)

A nagyvárosban élő romániai felhasználók nagyobb valószínűséggel rendelkeztek alapszint feletti digitális kompetenciával, míg az alapszint alatti digitális kompetencia a nagyvárosi (43 százalék) és a vidéki (44 százalék) környezetben hasonló arányban jellemző. A 4. táblázatban felsorolt közép-kelet-európai országok esetében is megállapítható, hogy a nagyvárosi lét növeli az alapszint feletti vagy legalábbis alapszintű digitális kompetenciaszint valószínűségét, míg a kisvárosi és a vidéki felhasználóknál inkább az alapszint alatti digitális kompetencia az előrelátható.

A digitális gazdaságban a legtöbb munkahely megköveteli a digitális kompetenciát, miközben a romániai vállalkozók 80 százaléka a digitálisan jártas szakemberek hiányáról számolt be (DESI 2019). Az Eurostat (2020) adatai szerint a fizikai munkát végző romániai lakosság 2 százaléka rendelkezett alapszint feletti és 18 százaléka alapszintű digitális kompetenciával. A nem fizikai munkát végzők 24 százaléka alap- 
szint feletti, 30 százaléka alapszintű és 38 százaléka alapszint alatti digitális képességekkel rendelkezett. Ezen a téren a követett közép-kelet-európai országok közül Románia és Bulgária a legrosszabbul, Magyarország, Csehország és Lengyelország a legjobban teljesítettek.

\begin{tabular}{|c|c|c|c|c|c|c|c|c|c|}
\hline \multirow{2}{*}{$\begin{array}{c}\text { Lakóhely/ } \\
\text { Ország }\end{array}$} & \multicolumn{3}{|c|}{$\begin{array}{c}\text { Alapszint alatti } \\
\text { digitális kompetencia }\end{array}$} & \multicolumn{2}{c|}{$\begin{array}{c}\text { Alapszintü digitális } \\
\text { kompetencia }\end{array}$} & \multicolumn{3}{c|}{$\begin{array}{c}\text { Alapszint feletti } \\
\text { digitális kompetencia }\end{array}$} \\
\cline { 2 - 11 } & $\begin{array}{c}\text { Nagy- } \\
\text { város }\end{array}$ & $\begin{array}{c}\text { Kis- } \\
\text { város }\end{array}$ & Vidék & $\begin{array}{c}\text { Nagy- } \\
\text { város }\end{array}$ & $\begin{array}{c}\text { Kis- } \\
\text { város }\end{array}$ & Vidék & $\begin{array}{c}\text { Nagy- } \\
\text { város }\end{array}$ & $\begin{array}{c}\text { Kis- } \\
\text { város }\end{array}$ & Vidék \\
\hline Románia & 43 & 41 & 44 & 22 & 23 & 18 & 17 & 9 & 5 \\
\hline Bulgária & 35 & 45 & 37 & 23 & 17 & 11 & 17 & 6 & 6 \\
\hline Magyarország & 26 & 34 & 35 & 26 & 23 & 21 & 34 & 24 & 17 \\
\hline Lengyelország & 31 & 37 & 37 & 26 & 24 & 19 & 29 & 18 & 17 \\
\hline Csehország & 18 & 26 & 28 & 37 & 36 & 36 & 35 & 24 & 20 \\
\hline Szlovákia & 26 & 30 & 30 & 29 & 27 & 30 & 33 & 27 & 23 \\
\hline EU28 & 25 & 28 & 32 & 25 & 25 & 24 & 39 & 32 & 25 \\
\hline
\end{tabular}

4. táblázat: A digitális kompetenciaszint megoszlása lakóhely alapján Romániában és öt közép-kelet-európai országban (\%) (Eurostat 2019 alapján)

A jövedelem mértéke és a digitális kompetenciaszint szintén összefüggnek egymással. A legkevesebben (52 százalék) a legalacsonyabb, a legtöbben (85 százalék) a legmagasabb jövedelmi kvartilisben rendelkeztek valamilyen szintű digitális kompetenciával (Eurostat 2020).

Az EU28 országából Romániában a legmagasabb az alapszint alatti és a legalacsonyabb az alapszint feletti digitális kompetenciával rendelkezők aránya (DESI 2019). A DESI (2019) humán tőkére vonatkozó dimenziójában, amelyhez a digitális kompetencia is tartozik, Románia egyetlen szempontból volt előnyös helyzetben, mégpedig az informatikai területen végzett egyetemi hallgatók számát illetően (6. pozíció a 28 országból).

\section{Értelmezés és következtetés}

A rogersi diffúziós modell alapján Románia az internet társadalmi adaptációjának telítettségi szakaszában van, amelyben a másodlagos digitális megosztottság kerül előtérbe (Molnár 2002). A másodlagos digitális megosztottság a digitális jártasság és tapasztalatok egyenlőtlen eloszlását jelenti, olyan szociodemográfiai jellemzők szerint, mint például az életkor, a nem, az iskolai végzettség, a foglalkozási helyzet és a jövedelem (van Deursen és van Dijk 2014; Helsper 2010), valamint a lakóhely és a régió (Ștefăniță és Ivan 2018; Helsper 2010). A Romániára vonatkozó statisztikai adatok másodelemzése megerősítette, hogy online térben a társadalmilag előnyös csoportokra a hasznos információkeresés, a társadalmilag hátrányosabb helyzetben 
lévő csoportokra a szórakozás és a kommunikáció túlsúlya a jellemző. Gazdasági, oktatási vagy politikai téren a romániai felhasználók nem folytatnak hasznos online tevékenységeket, viszont társadalmi és egyéni téren kihasználják a digitális lét előnyeit.

A digitális megosztottság összefügg a hagyományos társadalmi egyenlőtlenségekkel (van Deursen és van Dijk 2014; Micheli 2015; Helsper 2012; Witte és Mannon 2010). Az Eurostat, a Tempo Online és a létező romániai kutatások nem nyújtanak elegendő adatot a romániai lakosság gazdasági-társadalmi helyzete és a digitális megosztottsága közötti szignifikáns összefüggések feltárására. Megállapítható azonban, hogy a digitális és társadalmi megosztottságot ugyanazok a tényezők befolyásolják (Pop 2016).

Romániára nézve érvényesnek tekinthetők Ragnedda (2018) forgatókönyvei a digitális és a hagyományos tőkék kapcsolatáról. A digitális tőkefelhalmozás valószínűbb a hagyományos tőkeformákkal rendelkező társadalmi szegmenseknél, míg a digitális és hagyományos tőkéket nélkülöző társadalmi csoportokra a többszörös lemaradás jellemző. Ragnedda köztes forgatókönyveinek első változata a romániai idős korosztályra érvényes. A második köztes forgatókönyv a romániai fiatal korcsoportokra illeszkedik. A digitális tőke birtoklása tekintetében a digitálisnak tekintett fiatalok között is egyenlőtlenségek tapasztalhatók, amelyek a származás, a család hagyományos és digitális tőkehiányához köthetők. Mivel a digitális tőke a hagyományos tőkék nélkül nehezen és csak kivételes esetekben hasznosítható, a fiatalok induló esélyegyenlőtlenségei digitális egyenlőtlenségekhez vezetnek. Ezt a tendenciát a romániai fiatalok körében az online műveltségről végzett kutatások is megerősítik (Velicu, Balea és Barbovschi 2019; Balea 2016; Fizeșan 2012).

Az európai digitális menetrend (Európai Bizottság 2010) kiemelten kezeli a digitális felzárkóztatás kérdését. A digitális felzárkóztatás a társadalmi felzárkóztatás útja is egyben (Niță 2010). A romániai lakosság iskolai végzettségi szintjének, foglalkoztatási helyzetének, jövedelmi szintjének javítása, valamint a hátrányos helyzetű régiók gazdasági integrációja mind a hagyományos társadalmi, mind a digitális egyenlőtlenségek feloldását elősegítené. Az ország digitális felzárkóztatásához öszszehangolt és szigorúan végrehajtott közpolitikai beavatkozásra van szükség (Ștefăniță és Ivan 2018).

A tanulmány hiányosságai közé tartozik az adatgyüjtés, ugyanis az elemzés az európai és romániai nyilvános statisztikai adatok másodelemzésére épül. A vizsgálati eredmények összecsengenek az elméleti részben bemutatott tendenciákkal a digitális megosztottság és a digitális tőkemegoszlás tekintetében. Az elemzések sürgetik a román társadalomban hátrányos helyzetű szegmensek felzárkóztatását az információs társadalom elvárásaihoz, különben az információs társadalom kihívásaira válaszolni képes és képtelen társadalomrészek teljesen elszakadnak egymástól. 


\section{Irodalom}

Andrés, Luis, David Cuberes, Mame Diouf és Tomás Serebrisky. "The diffusion of the Internet: A cross-country analysis.” Telecommunications Policy 34 (2010): 323-340.

Balea, Bianca. "Digital natives or not? How do Romanian adolescents cross the boundaries of internet common use?” Studia UBB Sociologica 61, no. 1 (2016): 59-76.

Barbovschi, Monica és Bianca Balea. "Closing the gap, are we there yet? Reflections on the persistence of second-level digital divide among adolescents in Central and Eastern Europe.” In Ragnedda, Massimo és Glenn W. Muschert (Szerkesztők). The Digital Divide. The internet and social inequality in international perspective. London, New York: Taylor \& Francis Ltd, 2013.

Bourdieu, Pierre. “Gazdasági tőke, kulturális tőke, társadalmi tőke.” In Angelusz Róbert (Szerkesztő). A társadalmi rétegződés komponensei. Válogatott tanulmányok, 156-177. Budapest: Új Mandátum, 1997[1986].

Csepeli György. “Digitális generáció.” Utolsó hozzáférés: 2021. június 24. http://www.csepeli.hu/pub/2003/csepeli_et_2003_45.pdf

DESI 2019. “The Digital Economy and Society Index (DESI). Country Report Romania.” Utolsó hozzáférés: 2021. június 24. https://ec.europa.eu/digital-single-market/en/desi

Dessewffy Tibor és Galácz Anna. "A dolgok új rendje. Technológiai diffúzió és társadalmi változás.” In Z. Karvalics László és Dessewffy Tibor (Szerkesztők). Internet.hu. Budapest: Aula 2003.

EU Kids Online. Utolsó hozzáférés: 2021. június 24.

http://www.lse.ac.uk/media-and-communications/research/research-projects/eu-kidsonline

Európai Bizottság 2010. “Az európai digitális menetrend.” Utolsó hozzáférés: 2021. június 24. https://www.europarl.europa.eu/factsheets/hu/sheet/64/az-europai-digitalis-menetrend

Európai Bizottság 2017. “Az egyenlőtlenség kezelése.” Utolsó hozzáférés: 2021. június 24. https://ec.europa.eu/info/sites/info/files/file_import/european-semester thematic-factsheet addressing-inequalities hu.pdf

Eurostat 2019, 2020. “Digital economy and society.” Utolsó hozzáférés: 2021. június 24. https://ec.europa.eu/eurostat/web/digital-economy-and-society/overview

Fizeșan, Bianca. "Digital engagement among Eastern European children.” Studia UBB Sociologica 57, no. 1 (2012): 83-99.

Globalfindex.worldbank. „The Global Findex database 2017.” Utolsó hozzáférés: 2021. szeptember 22. https://globalfindex.worldbank.org/

Hargittai Eszter. "Second-level digital divide: Differences in people's online skills." First Monday 7, no. 4 (2002). http://www.firstmonday.org/issues/issue7_4/hargittai/

Hargittai Eszter. "Whose space? Differences among users and non-users of social network sites.” Computer Mediated Communication 13, no. 1 (2007): 276-297.

Hargittai Eszter. "Digital Na(t)ives? Variation in Internet skills and uses among members of the Net generation.” Sociological Inquiry 80, no. 1 (2010): 92-113.

Helsper, Ellen Johanna. "Gendered Internet use across generations and life stages." Communication Research 37, no. 3 (2010): 352-374.

Helsper, Ellen Johanna. "A corresponding fields model for the links between social and digital exclusion.” Communication Theory 22, no. 4 (2012): 403-426. 
ITU International Technological Union. "Measuring the Information Society. Report.” Geneva: ITU Publications, 2018.

Livingstone, Sonia és Ellen Johanna Helsper. "Children, internet and risk in comparative perspective.” Journal of Children and Media 7, no. 1 (2013): 1-8.

Livingstone, Sonia és Ellen Johanna Helsper. "Balancing opportunities and risks in teenagers' use of the Internet. The role of online skills and family context." New Media\&Society 12, no. 2 (2010): 309-329.

McKeown, Anthony. Overcoming Information Poverty. London, New York: Chandos Publishing, E-book, 2016.

Micheli, Marina. "What is New in the Digital Divide? Understanding Internet Use by Teenagers from Different Social Backgrounds.” In Robinson, Laura, Shelia R Cotten, Jeremy Schulz, Timothy M. Hale és Apryl Williams (Szerkesztők). Communication and Information Technologies Annual, 55-87. Emerald Group Publishing Limited, 2015.

Molnár Szilárd. “A digitális megosztottság értelmezési kerete.” Információs Társadalom II., 4. szám (2002): 482-101.

Net Children Go Mobile. Utolsó hozzáférés: 2021. június 24. https://netchildrengomobile.eu/

Niță, Viorel. "An Extended Approach to E-Inclusion and its Implications for Romania." Romanian Journal of European Affairs 11, no 1 (2011): 63-79.

Norris, Pippa. Digital Divide. Cambridge: CUP, 2001.

Park, Sora. Digital Capital. London: Palgrave Macmillian, 2018.

Pop, Cristian-Ioan. Clase sociale în România. Cluj-Napoca: UPC, 2016.

Ragnedda, Massimo. The Third Digital Divide. A Weberian Approach to Digital Inequalities. London, New York: Routledge Publishing, 2017.

Ragnedda, Massimo. “Conceptualizing Digital Divide.” Telematics and Informatics 35, no. 8 (2018): 2366-2375.

Ragnedda, Massimo. "Reconceptualising the digital divide.” In Mutsvairo, Bruce és Massimo Ragnedda (Szerkesztők). Mapping the Digital Divide in Africa. A mediated Analysis, 27-43. Amsterdam: Amsterdam University Press, 2019.

Ragnedda, Massimo és Maria Laura Ruiu. Digital Capital. A Bourdieusien Perspective on the Digital Divide. Bingley: Emerald Publishing House, 2020.

Rogers, Everett M. Diffusion of Innovations. New York: Free Press, 1995.

Saren, Mike. "A classification and review of models of the intra-firm innovation process." $R \& D$ Management 14, no.1 (1984): 11-24.

Scheerder, Anique J., Alexander J. A. M. van Deursen és Jan A. G. M. van Dijk. "Determinants of Internet Skills, Use and Outcomes. A Systematic Review of the Second- and Third-Level Digital Divide.” Telematics and Informatics 34, no.8 (2017): 1607-1624. http://dx.doi.org/10.1016/j.tele.2017.07.007

Scheerder, Anique J., Alexander J. A. M. van Deursen és Jan A. G. M. van Dijk. "Negative outcomes of Internet use: A qualitative analysis in the homes of families with different educational backgrounds.” The Information Society 35, no.5 (2019): 286-298.

Ștefăniță, Oana és Loredana Ivan. "Characteristics of the Digital Divide in Romania and Differences in Internet Use in Comparison with Internet Use in Europe.” Journal of Media Research 11, no.2 (2018): 5-21.

Tempo Online 2019. Utolsó hozzáférés: 2021. június 24. http://statistici.insse.ro:8077/tempo-online/\#/pages/tables/insse-table 
The Digital Literacy and Multimodal Practices of Young Children. Utolsó hozzáférés: 2021. június 24. http://digilitey.eu/

Tichenor, Phillip J., George A. Donohue és Clarice N. Olien. "Mass Media Flow and Differential Growth in Knowledge.” The Public Opinion Quarterly 34, no. 2 (1970): 159-170.

Tufă, Laura. "Diviziunea digitală. Accesul şi utilizarea internetului în România, comparativ cu ţările Uniunii Europene.” Calitatea Vieţii 21, no. 1-2 (2010): 71-86.

van Deursen, Alexander J. A. M. és Ellen Johanna Helsper. "The third-level digital divide: Who benefits most from being online?” In Robinson, Laura, Shelia R. Cotten, Jeremy Schulz, Timothy M. Hale és Apryl Williams (Szerkesztők). Communication and Information Technologies Annual, 29-52. Emerald Group Publishing Limited, 2015.

van Deursen, Alexander J. A. M. és Ellen Johanna Helsper. “Collateral benefits of Internet use: Explaining the diverse outcomes of engaging with the Internet.” New Media \& Society 20, no. 7 (2018): 2333-2351. http://dx.doi.org/10.1177/1461444817715282

van Deursen, Alexander J. A. M. és Jan A. G. M. van Dijk. "The digital divide shifts to differences in usage.” New Media \& Society 16, no. 3 (2014): 507-526.

van Deursen, Alexander J. A. M. és Jan A. G. M. van Dijk. "Toward a Multifaceted Model of Internet Access for Understanding Digital Divides: An Empirical Investigation.” Information society 31, no.5 (2015a): 379-391.

van Deursen, Alexander J. A. M. és Jan A. G. M. van Dijk. "Internet skill levels increase, but gaps widen: a longitudinal cross-sectional analysis (2010-2013) among the Dutch population.” Information, Communication \& Society 18, no.7 (2015):782-797.

Van Dijk, Jan A. G. M. The Deepening Divide. Inequality in the Information Society. London: Sage Publishing, 2005.

Van Dijk, Jan A. G. M. One Europe, Digitally Divided. In Chadwick, Andrew és Phillip N. Howard (Szerkesztők). The Handbook of Internet Politics, 288-304. Abingdon: Routledge, 2008.

Velicu, Anca, Bianca Balea és Monica Barbovschi. "Acces, utilizări, riscuri și oportunități ale internetului pentru copiii din România. Rezultatele EU Kids Online 2018.” EU Kids Online és DigiLiv-REI, 2019.

Viswanath, Kasisomayajula és John R. Finnegan “A tudásszakadék hipotézise. Huszonöt évvel később.” In Angelusz Róbert, Tardos Róbert és Terestyéni Tamás (Szerkesztők). Média, nyilvánosság, közvélemény, 187-192. Budapest: Gondolat, 2007[1996].

Witte, James C. és Susan E. Mannon. The internet and social inequalities. London: Routledge, 2010. 